NBER WORKING PAPER SERIES

\title{
INTERNATIONAL TRADE BETWEEN \\ CONSUMER AND CONSERVATIONIST \\ COUNTRIES
}

\author{
James Brander \\ M. Scott Taylor
}

Working Paper 6006

\section{NATIONAL BUREAU OF ECONOMIC RESEARCH \\ 1050 Massachusetts Avenue \\ Cambridge, MA 02138 \\ April 1997}

We thank Brian Copeland, Josette McGregor, Gordon Munro, Philip Neher and seminar participants at the University of Calgary for helpful comments and discussions. Financial support from the Social Sciences Research Council of Canada, the Canadian Institute for Advanced Research, and from the UBC Centre for International Business Studies is gratefully acknowledged. This paper is part of NBER's research program in International Trade and Investment. Any opinions expressed are those of the authors and not those of the National Bureau of Economic Research.

(C) 1997 by James Brander and M. Scott Taylor. All rights reserved. Short sections of text, not to exceed two paragraphs, may be quoted without explicit permission provided that full credit, including $($ notice, is given to the source. 
International Trade Between Consumer

and Conservationist Countries

James Brander and M. Scott Taylor

NBER Working Paper No. 6006

April 1997

International Trade and Investment

\section{ABSTRACT}

We consider trade between a "consumer" country with an open access renewable resource and a "conservationist" country that regulates resource harvesting to maximize domestic steady-state utility. In what we call the "mild overuse" case, the consumer country exports the resource good and suffers steady-state losses from trade, as suggested by the "conventional wisdom" that weak resource management standards confer a competitive advantage on domestic firms in the resource sector but cause welfare losses. Strikingly, however, when the resource stock is most in jeopardy, the conservationist country exports the resource good in steady state and both countries experience gains from trade.

James Brander

Faculty of Commerce

University of British Columbia

2053 Main Mall

Vancouver, BC V6T $1 Z 2$

CANADA

and NBER

jbrander@unixg.ubc.ca
M. Scott Taylor

Department of Economics

University of British Columbia

997-1873 East Mall

Vancouver, BC V6T 1Z2

CANADA

and NBER

taylor@econ.ubc.ca 


\section{Introduction}

It is commonly argued that a country adopting weak resource management standards confers a "competitive advantage" on firms in its domestic resource sector. Furthermore, we would normally expect that trade liberalization would lead such a country to expand production and exports of resource-intensive products. Moreover, if these low resource management standards reflect genuine market failure (as in the case of open access resources), then we might expect trade liberalization to cause a reduction in the country's welfare. Thus there is a possible linkage from low resource management standards to increased (and excessive) resource exports and ultimately to lower welfare. Concerns of this type have entered the international policy debate in many forums and even enjoy the status of "conventional wisdom" in some circles. $^{\prime}$

Our paper investigates this conventional wisdom using a simple two-country general equilibrium model incorporating a renewable resource sector. To make our points as clearly as possible we adopt a very stark model in which the two countries have potentially identical nationally-owned renewable resource stocks but differ sharply in their resource management regimes. We might think of the two countries as extremes or archetypes of resource management. One country, referred to as a "consumer" country, has lax resource management practices in that the resource is subject to open accesș. The other country, referred to as the "conservationist" country, has very strict resource management practices that serve to maximize national steady state utility. Apart from these (exogenous) differences in resource management regimes, the two countries are identical. ${ }^{2}$

We find an important class of cases in which the conventional wisdom (as we have characterized

'Discussions of this type can be found in many places, including documents provided by the United Nations Conference on Trade and Development (UNCTAD, 1994), the Organization for Economic Cooperation and Development (OECD,1995), and the General Agreement on Tariffs and Trade (GATT, 1992).

${ }^{2}$ Differences across countries in resource abundance, technologies, etc. can be added to our analysis in a straightforward way. One can also readily extend the analysis to many conservationist and many consumer countries. These (and other) possibilities should become apparent as we proceed. 
it) is overturned. Specifically, the conservationist country has a comparative advantage in the resource good in steady state and exports this good under free trade. Furthermore, both countries experience steady state gains from trade in this case. This possibility arises in what we refer to as the "severe overuse" case, which means that the consumer country would severely overuse the resource good in autarky. The other possibility is "mild overuse". In this case the consumer country exports the resource good in steady state and loses from trade, in accordance with the conventional wisdom. To some extent there is a hopeful message in our results, as they suggest that when resource stocks are most in jeopardy, free trade has the effect of shifting production from the "low standard" country to the "high standard" country, allowing the resource stock in the low standard country to rebuild.

The key insight is simply that a well-managed resource can be a relatively cheap one in the long run. Correspondingly, a resource that is over-used in the short run may provide short run comparative (and competitive) advantage but it may be sufficiently degraded to induce long run comparative disadvantage. Stated in this way, the point seems uncontroversial, but it is markedly under-emphasized and perhaps underappreciated in the policy debate on trade and resource management.

For example, one of the major concerns expressed by some environmentalists is that low resource management standards will tend to be "contagious" across countries. In an influential article in Scientific American, Herman Daly (1993, p. 52) states that "When firms produce under the most permissive standards and sell their products elsewhere without penalty, they press on countries with higher standards to lower them. In effect, unrestricted trade imposes lower standards". This argument presumes that low standards provide a competitive advantage, without any apparent recognition that such advantages may be short-lived, or that it may be in the long run interest of domestic producers and consumers to encourage their own governments to regulate resource use efficiently. Our analysis serves to focus attention on such effects.

Two key assumptions are central to the analysis. The first is that harvesting the resource becomes more difficult as the stock is depleted. Therefore, a higher resource stock means greater productivity in harvesting. This in turn ensures that a more tightly regulated resource sector with a correspondingly higher 
resource stock has greater harvesting productivity. A second key assumption is that the natural growth of the resource stock is given by a standard compensatory (concave) growth function of the type commonly used in resource economics. In fact, we assume specific functional forms for resource harvesting productivity and for natural resource growth, but it is these general properties of the functions that are of central importance.

This paper draws on the traditional theory of renewable resources. Much of this theoretical development is provided in Clark (1990). Other valuable overviews include Neher (1990) and Munro and Scott (1985). The classic paper on the open access problem is Gordon (1954), and some of the basic elements of our resource model derive from Schaefer (1957). Renewable resource dynamics are discussed in many papers. Relevant examples include Brown (1974), Clemhout and Wan (1991), Plourde (1971), and Smith (1968).

Our basic model of international trade is a dynamic version of the Ricardian trade model. The static Ricardian model is set out in most textbooks in international trade, and the renewable resources version is formalized in Brander and Taylor $(1995,1996)$. Our paper is an example of the general theory of the second best as developed by Lipsey and Lancaster (1957) and is also related to the "distortions" literature in international trade as described, for example, in Bhagwati (1971). There has been relatively little relevant work on trade in renewable resources. Some review material is available in Kemp and Long (1984). Recent work would include Barbier et. al. (1994). A discussion and analysis of enforcement of property rights in renewable resources can be found in Clark et. al. (1993).

This paper also provides a contrast to Chichilnisky $(1991,1994)$ which show that a country with incomplete property rights in the resource sector will be a net exporter of the resource good and will exploit its resource even more when it opens up to free trade. In our model the dynamic steady state effects of severe resource overuse are, in essence, opposite to this pattern.

The remainder of the paper is organized as follows. Section 2 of the paper sets out the characteristics of the renewable resource component of our model. Section 3 then embeds this renewable resource in an 
autarkic competitive general equilibrium model of production and consumption. The autarky versions of both the "consumer" regime and the "conservationist" regime are developed in this section. Section 4 considers the effects of international trade while Section 5 discusses some qualifications and extensions. Section 6 contains concluding remarks, and there is an appendix containing some of the detailed calculations.

\section{The Renewable Resource Model}

Before proceeding to the Ricardian general equilibrium setting, we describe the basic structure of renewable resource growth. We have in mind a renewable resource such as a forest or a fish species. The biological structure of the renewable resource as described in this section is assumed to be the same in both countries. Within a given country, the stock of the resource at time $t$ is denoted by $S(t)$. The natural growth rate of the resource, $G$, depends on the existing stock. The net change in the stock at time $t$ is the natural growth rate, $G(S(t))$ minus the harvest rate, $H(t)$.

$$
d S / d t=G(S(t))-H(t)
$$

We assume, as expressed in equation (2), that resource growth is given by a specific functional form of the logistic type. ${ }^{3}$

$$
\mathrm{G}(\mathrm{S})=\mathrm{rS}(1-\mathrm{S} / \mathrm{K})
$$

Variable K represents the maximum possible size or "carrying capacity" for the resource stock in that further growth cannot occur once S equals K. Variable $\mathrm{r}$ is the intrinsic or uncongested growth rate. Proportional growth rate $G(S) / S$ would be approximately equal to $r$ if $S$ were sufficiently small that congestion effects were negligible. $G$ reaches a unique maximum at $S=K / 2$, and is increasing for $S<K / 2$ and decreasing for $\mathrm{S}>\mathrm{K} / 2$.

The functional form for the harvest rate, $\mathrm{H}$, must be derived from the economic incentives that

${ }^{3}$ The basic structure of results does not require the growth function. What is required is the general "compensatory" (bent-over) shape. However, adopting a specific functional form allows for greater concreteness, more expositional clarity, and simpler algebra. Actual growth dynamics for renewable resources vary substantially from resource to resource, but the logistic form captures key properties that are thought to be important. It is probably the most commonly used functional form for renewable resource dynamics. 
control the behavior of harvesters. It is these harvesting incentives that will differ between the two countries, as discussed in the next section.

\section{General Equilibrium with a Renewable Resource: Autarky}

\subsection{Consumer and Conservationist Countries}

At this stage we define more precisely what we mean by consumer and conservationist countries. In the consumer country, the resource is a common property resource subject to open access (i.e. there is no property rights regime or regulatory regime that limits access to the resource). Harvesting of the resource is carried out by profit-maximizing harvesters under conditions of free entry. In this situation, harvesting occurs until the current return to a representative entrant is just equal to the entrant's current cost. No harvester has any incentive to delay harvesting as long as positive current rents are available, because of the legitimate expectation that someone else will harvest the resource instead. The harvest level is therefore determined by a current-period zero-profit requirement for the representative harvester (or, if harvesters were asymmetric, for the marginal harvester). For the conservationist country, we simply assume that the regulatory objective is to maximize sustainable utility (i.e. to maximize steady state utility) and that this objective is achieved through some combination of appropriate property rights and regulatory instruments.

It is worth noting that the consumer country could be given an alternative interpretation. Specifically, an outcome identical to that arising under open access would occur if the resource were carefully regulated so as to maximize the current national utility at each moment in time. More pedantically, we could say that regulatory objective was to maximize the present discounted value of utility, but the discount rate was infinite. Correspondingly, the conservationist regulatory objective of maximizing steady state utility is often associated with a zero discount rate (as discussed further in Section 5). Thus the contrast between the consumer and conservationist countries could be seen as a contrast between extreme impatience and extreme patience. This discount rate interpretation makes it clear that the two countries are polar extremes. However, these two extreme cases have the analytical convenience that they both reduce to essentially static problems and can therefore be readily solved. The principles that emerge in this extreme comparison should also apply 
to intermediate comparisons, although proving this assertion is beyond the scope of the present paper. In the interest of expositional economy, we will refer primarily to the interpretation based on comparative property rights (i.e. on open access and full regulation) in the rest of the paper. This choice is partly determined by our view that cross-country differences in property rights are particularly important in current policy debates.

We now introduce an explicit Ricardian general equilibrium setting. The basic autarky model structure for the open access regime follows Brander and Taylor $(1995,1996)$. The analysis of the conservationist regime is original to this paper, as is the subsequent analysis of trade patterns. We begin by describing those aspects of the economic environment that are common to both countries. Each country is endowed with a common property resource located entirely within its boundaries. The countries can potentially engage in trade, but we first examine the no-trade or autarkic equilibrium for each country. In carrying out the analysis we use explicit functional forms for utility and production. In combination with the

logistic form of resource growth, these functional forms allow us to obtain closed-form solutions for various quantities of interest. The specific functional forms can be generalized, although with some increase in algebraic difficulty.

\subsection{Production and Supply:}

Each country produces and consumes two goods. We first specify the economic environment for one of the countries under autarky (i.e. without trade), focussing on those elements that are common to both countries. (Recall that the two countries have identical economic environments except for the renewable resource management regime.) One good, $\mathrm{H}$, is the harvest or "resource good" arising from a renewable resource stock and $M$, the other good, can be thought of as "manufactures." Good $M$ is treated as a numeraire good whose price is normalized to be 1 . Aside from the stock, $S$, of the renewable resource, the only additional factor of production is labor, L. Manufactures are produced with constant returns to scale using labor as the only input. By choice of units, one unit of labor input produces one unit of good M. Using $L_{M}$ to denote the labor used in manufacturing, we can write

$$
\mathrm{M}=\mathrm{L}_{\mathrm{M}}
$$


As the price of good $M$ is 1 , it follows from (3) that the labor's value of marginal product in the manufacturing sector is 1 . Assuming competitive labor markets, the wage, w, is also 1 if manufactures are produced.

We assume that the harvesting function displays constant returns to labor (holding the resource stock fixed). In particular, we assume that the harvesting production function can be written as

$$
\mathrm{H}^{\mathrm{P}}=\alpha \mathrm{SL}_{\mathrm{H}}
$$

where $\mathrm{L}_{\mathrm{H}}$ is the amount of labor used in resource harvesting. The superscript $\mathrm{P}$ stands for "production", so $\mathrm{H}^{\mathrm{P}}$ is the amount of the resource good that is produced. This production structure is often referred to as the Schaefer harvesting production function (after Schaefer (1957)). It implies that, at a moment in time, production of the harvest is much like production of manufactures. Given the stock size, if we double the labor input, we double-the harvest rate. (To have any actual effect on the stock, this harvest rate has to continue over some positive interval of time.) The property that the harvest rate shows constant returns in the stock is less obvious. It is, however, a commonly made assumption in resource economics. The primary motivation comes from fishing, where the productivity of fishing effort is approximately proportional to the available stock. Coefficient $\alpha$ measures the productivity of labor conditional on a given stock. It is sometimes useful to consider the labor input per unit of output in harvesting, denoted $a_{L H}$.

$$
a_{L H}(S)=L_{H} / H^{P}=1 / \alpha S
$$

\subsection{Utility, Consumption, and Demand:}

A representative consumer is endowed with one unit of labor and is assumed to have instantaneous utility given by the following Cobb-Douglas utility function

$$
u=h^{\beta} m^{1-\beta}
$$

where $h$ represents individual consumption of the resource good and $m$ is individual consumption of manufactures. The representative consumer maximizes utility (at each moment in time) taking price $p$ and wage $w$ as exogenous to the consumption choice. Price $p$ is the nominal price of the resource good and, as the manufactured good is the numeraire and therefore has a price of 1 , price $p$ is also the relative price of the 
resource good. The instantaneous budget constraint is given by:

$$
\mathrm{ph}+\mathrm{m}=\mathbf{I}
$$

where I is a consumer's total income consisting of wage income w, plus a rebated share of any government revenues raised by regulations limiting access. In the consumer country these revenues are zero, but in the conservationist country these revenues are positive. Both goods are assumed to be non-durable and are therefore consumed as they are produced. The only form of saving or investment in the model arises from changes in the resource stock caused by harvesting the resource at a rate that differs from its growth rate. Maximizing (6) subject to (7) yields the following demand functions:

$$
h=I \beta / p \quad m=I(1-\beta)
$$

Domestic population is taken to be equal to the labor force, $\mathrm{L}$, so aggregate consumption demands for $\mathrm{H}$ and $\mathrm{M}$ are given by

$$
H^{\mathrm{D}}=\mathrm{hL}=\mathrm{I} \beta \mathrm{L} / \mathrm{p} \quad \mathrm{M}^{\mathrm{D}}=\mathrm{mL}=\mathrm{I}(1-\beta) \mathrm{L}
$$

where the superscript D stands for demand.

\subsection{Steady state Relative Supply and Demand}

In this paper we focus on steady state analysis, where the steady state is defined as a situation in which the resource stock, $S$, is stationary. We analyze the model using using relative demand and supply constructs that are common to much of the international trade literature. The relative demand and supply formulation of this problem is original to this paper and is not available in Brander and Taylor (1995, 1996). We adopt it here because it is very useful for comparing consumer and conservationist management regimes. From equation (9) we can write the relative demand of the harvest good to manufactures as:

$$
H^{D} / M^{D}=[\beta /(1-\beta) p]
$$

Because tastes are homothetic, the relative demand for the two goods is only a function of their relative price $\mathrm{p}$ and is independent of income and population size. Therefore, even though income levels will differ across countries because of differences in resource management regimes, both countries will share the same relative demand. This relative demand curve characterizes demand conditions both in steady state and out of steady 
state. We now derive the steady state relative supply curve. It follows from expression (1) that a steady state arises when harvest $H^{p}$ equals resource growth $G$. Using expression (2), this steady state equality of harvest and growth can be written as

$$
H^{\mathrm{P}}=r S(1-S / K)
$$

To determine the supply of manufacturing, note that manufacturing output is fully determined by the quantity of labor not used in harvesting and therefore left to undertake manufacturing. The overall labor supply constraint is given by

$$
\mathrm{L}=\mathrm{L}_{\mathrm{H}}+\mathrm{L}_{\mathrm{M}}
$$

Recalling (from (3)) that $M^{P}=L_{M}$, expression (12) implies that $M^{P}=L_{M}=L-L_{H}=L-H^{P} a_{L H}$ Using expression (11) to substitute for $\mathrm{H}^{\mathrm{P}}$ and expression (5) to substitute for $\mathrm{a}_{\mathrm{LH}}$ yields

$$
M^{P}=L-(r / \alpha)(1-S / K)
$$

Dividing (11) by (13) allows us to obtain the steady state relative supply of the harvest to manufactures as a function of the steady state stock $S$.

$$
\mathrm{H}^{\mathrm{P}} / \mathrm{M}^{\mathrm{P}}=[\mathrm{rS}(1-\mathrm{S} / \mathrm{K})] /[\mathrm{L}-(\mathrm{r} / \alpha)(1-\mathrm{S} / \mathrm{K})]
$$

We have written (14) as a function of the resource stock and have not yet expressed relative supply as a function of the price of the resource good.

Before going on to derive relative supply as a function of $p$ we note that specialization as well as diversified production can be considered. Either the harvest or manufacturing output could be zero in principle. In order to keep our analysis from becoming excessively taxonomic, however, we focus our attention on economies that are diversified in steady state. At the level of aggregation implicit in our analysis this seems reasonable on empirical grounds as we are interested in economies that produce both resource goods and other goods. Formally, we can rule out the possibility of either economy specializing in the resource good by a simple restriction on parameters. From (13) if $L>(r / \alpha)(1-\mathrm{S} / \mathrm{K})$ then manufacturing cannot be zero. As $(1-\mathrm{S} / \mathrm{K})$ is always positive but less than 1 (as implied by (2)), this condition must hold if 


$$
\mathrm{L}>\mathrm{r} / \alpha \text {. }
$$

Thus if the labor force is sufficiently large, then the country cannot specialize in resource harvesting ${ }^{4}$.

Expression (14) can be used to derive the steady state relative supply curve as a function of price. However, the relationship between $\mathrm{p}$ and $\mathrm{S}$ will depend on the resource management regime. We must therefore consider the consumer and conservationist countries separately to derive relative supply curves.

\subsection{The Consumer Country}

In the consumer country, production in both sectors is carried out by competitive profit-maximizing firms under conditions of free entry. There is no regulation limiting access to the resource, nor any production tax on the harvest. As a result, whenever production is positive, the price of the resource good must equal its unit cost. It follows (using (5)) that

$$
\mathrm{p}=\mathrm{wa}_{\mathrm{LH}}=\mathrm{w} / \alpha \mathrm{S}
$$

where $w$ is the wage.

This incorporates the open-access assumption, because it means that labor costs are the only explicit cost of production; there is no explicit rental cost for using S. Labor is freely mobile between the two sectors and must therefore command the same wage in both sectors. Recalling (as implied by (3)) that $w=1$ if manufactures are produced, expression (16) becomes

$$
p=1 /(\alpha S)
$$

When production is diversified, condition (16a) links the resource price directly to the resource stock. We can use (16a) to construct the consumer country's relative supply curve as a function of the relative price, $p$, of the harvest good. Rewriting (16a) as $S=1 / \alpha p$ and substituting this into (14) yields

$$
H^{\mathrm{P}} / \mathrm{M}^{\mathrm{P}}=[\mathrm{r} /(\alpha \mathrm{p})][1-1 /(\alpha \mathrm{pK})] /[\mathrm{L}-(\mathrm{r} / \alpha)(1-1 /(\alpha \mathrm{pK}))]
$$

Equation (17) is the consumer country relative supply curve, showing the relative supply of resource good

This is an application of Proposition 7 in Brander and Taylor (1995). There we show that if (15) holds then a small open economy can never specialize in the resource good. The intuition is simply that if all labor is allocated to harvesting, and (15) holds, then the resource would be driven to extinction. 
$\mathrm{H}$ to manufactures $\mathrm{M}$ as a function of the relative price of the resource good.

One interesting feature of this relative supply curve is that it is backward-bending. ${ }^{5}$ From (16a) it is clear that the resource good price rises as the stock falls. Furthermore, as the stock approaches zero, the supply price approaches infinity. In addition, expression (11) implies that the harvest approaches zero as the resource stock approaches zero. Thus, as the resource stock falls and the resource price rises, the numerator of (14) approaches zero, while the denominator remains strictly positive. Therefore, the relative supply curve approaches zero (i.e. it approaches the vertical axis) as the resource good price gets very large.

Conversely, if the resource good price is low, then the stock must be large, and a sufficiently low price would make it unprofitable for any harvesting to take place. More specifically, if $p<1 /(\alpha \mathrm{K})$, then the marginal value product of labor in the resource sector, which cannot exceed $p \alpha \mathrm{K}$, must be less than 1 . In this case labor is worth more in manufacturing (where its marginal value product is 1 ) than in harvesting and no resource good would be produced. Thus harvesting (and the relative supply of the resource good) approach zero both for very high and sufficiently low (but strictly positive) prices, implying that the supply curve is backward-bending. Proposition 1 describes the properties of this relative supply curve more precisely.

Proposition 1. The consumer country's relative supply of the harvest good to manufactures is backward bending. Moreover,

i) for $p \leq 1 / \alpha \mathrm{K}$, the relative supply $H / M$ is zero, while for any finite price $p>1 / \alpha K$, the relative supply $H / M$ is positive;

ii) there exists a price $\mathrm{p}^{c}$ such that for $\mathrm{p}<\mathrm{p}^{c}$, the relative supply $\mathrm{H} / \mathrm{M}$ is increasing in $\mathrm{p}$, and for any $\mathrm{p}>\mathrm{p}^{c}$, the relative supply $\mathrm{H} / \mathrm{M}$ is decreasing in $\mathrm{p}$.

iii) the critical price, $p^{c}$, is given by $p^{c}=1 / \alpha S^{c}$ where $S^{c}$ is the stock level where (14) is at a maximum.

iv) the critical stock $S^{C}$ is an increasing function of $L$, and a decreasing function of $r$.

5 The observation that an open access supply curve for a renewable resource harvest is backward bending was first made, in a partial equilibrium setting, by Copes (1970). We are not aware of any attempts (prior to the current paper) to analyze this point in a general equilibrium model. 
Proof: See Appendix.

To understand the economic logic of backward bending suppy, consider an initial steady state resource stock greater than $\mathrm{K} / 2$. If the resource price increases slightly, then more harvestors will move into the resource sector in response to the incipient rents available. This will reduce the steady state stock, as implied by (16a). With a lower stock it follows from growth function (2) (with $S>K / 2$ ) that the steady state harvest must be higher. Therefore the steady state harvest is increasing in the resource price when $S>K / 2$. Also, because labor in the resource sector has increased, less labor is available for manufacturing and manufacturing output must fall. Consequently, the relative supply curve is upward sloping whenever $S>K / 2$.

Alternatively, suppose we start from a steady state stock less than $\mathrm{K} / 2$ (and a correspondingly high price, as implied by (16a)). If we increase the resource price slightly, then once again new harvestors will be attracted to the resource sector until rents are driven to zero through resource depletion (i.e. until (16a) comes into alignment again). From (2) the decline in the stock causes the steady state harvest to decline when $\mathrm{S}<\mathrm{K} / 2$, so output falls even though price rises and harvesting labor increases. With more labor in the resource sector, manufacturing labor and output decline. Thus both manufactures and resource output decline when resource price $p$ rises if the stock is less than $K / 2$.

For the relative supply curve to bend backwards the fall in the harvest must eventually exceed that of manufactures. From the denominator of (14) note that the fall in manufactures production is a linear function of the stock. From the numerator of (14) we know that the harvest is a concave function of the stock. Therefore, as the stock falls, the reduction in the harvest becomes increasingly large while the reduction in manufactures remains constant. This ensures that the supply curve eventually bends backward as the price rises. It should be clear from this discussion that the backward bending portion of the supply curve corresponds to a region of inefficient and excessive harvesting of the resource good ${ }^{6}$ in that more

${ }^{6}$ Even in a fully optimizing model the supply curve for the harvest may also bend backwards, as shown by an example provided by Clark (1990, ch. 5). The interpretation of the backward bending portion of the supply curve is quite different in that case and, of course, does not correspond to any inefficiency. 
labor than necessary is used to provide a given steady state harvest in this range.

In Figure 1, we depict three possible autarkic steady states for the consumer country. One possible autarkic equilibrium is at point $A^{7}$. In this case the solution occurs on the upward sloping section of the relative supply curve. However, steady states at points like $\mathrm{B}$ and $\mathrm{C}$ are also possibilities, depending on

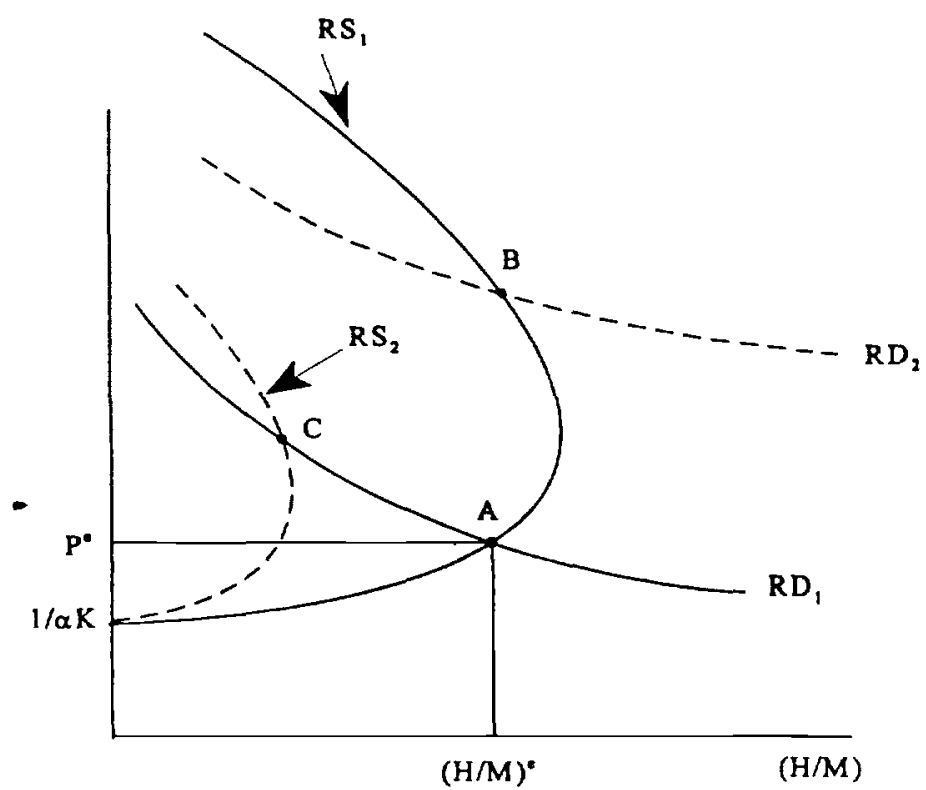

Figure 1: Autarky With An Open-Access Resource: the Consumer Country

parameter values. For example, if we start from steady state $A$ and increase the "taste" for the resource good (as represented by $\beta$ ) then the relative demand curve would be shifted out as illustrated by dashed line $\mathrm{RD}_{2}$. In this case, the autarkic equilibrium would instead occur at a point like $\mathrm{B}$, along the backward bending portion of the relative supply curve.

If tastes were such that $\mathrm{RD}_{1}$ was the relative demand curve, but if the intrinsic resource growth rate $r$ were lowered or if population size $L$ were raised, then the relative supply curve would be shifted in and it would begin its backward bending segment earlier (i.e. at a lower relative price). In this case, the relative

${ }^{7}$ An important property of the relative supply curve is that the backward bending portion not begin at too low a relative price. If the backward bending portion does begin at a sufficiently low price, then multiple equilibria are possible. However, reasonable restrictions on functional forms yield a unique solution, as depicted in the diagram. 
supply might be as shown by the dashed line $\mathrm{RS}_{2}$ and the autarkic equilibrium would occur at a point such as C. Again, autarky occurs on the backward bending portion of the relative supply curve. It is clear from (17) (dividing both numerator and denominator by $r$ ) that a decrease in the ratio $r / L$ shifts the relative supply curve in towards the vertical axis for any given $\mathrm{p}>1 / \alpha \mathrm{K}$. Brander and Taylor (1995) adopt the ratio " $r / \mathrm{L}$ " as the appropriate measure of relative factor abundance for considering trade flows."

By setting relative demand in (10) equal to relative supply in (17), and using (10), (11), and (16) we can obtain solutions for both the resource stock and the relative price of the resource good.

$$
\begin{gathered}
\mathrm{S}=\mathrm{K}(1-\alpha \beta \mathrm{L} / \mathrm{r})>0 \\
\mathrm{p}=\mathrm{l} /[\alpha \mathrm{K}(1-\alpha \beta \mathrm{L} / \mathrm{r})]>0
\end{gathered}
$$

As shown in Brander and Taylor (1995), a positive autarky steady state stock exists if the country is sufficiently resource abundant that $r / L>\alpha \beta$. We assume throughout the paper that this condition holds. This condition could be written as $r>\alpha \beta L$, which is really a condition on $G^{\prime}(0)$ in that $G^{\prime}(0)=r$. In order for a non-zero steady state to emerge, $G^{\prime}(0)$ must exceed $\alpha \beta L$. Comparable conditions are established in Brown (1974) and Clemhout and Wan (1991).

\subsection{The Conservationist Country}

We now consider the specific features of the conservationist country. The defining characteristic of this country is that resource harvesting is controlled so as to maximize steady state utility for the representative citizen-consumer. As mentioned earlier, this is consistent with the absence of discounting. Our approach has two principle advantages. One advantage has to do with algebraic convenience. For positive but finite discount rates, this is an algebraically challenging problem to solve. (Similar optimization problems for partial equilibrium models without international trade are solved in Clark (1990) and Neher(1990).) As we do not wish to focus on the dynamic control theoretic aspects of the problem, focusing

${ }^{8}$ Brander and Taylor (1995) show that $r / L$ determines the pattern of trade for a small open economy of what we refer to here as the consumer type. See the discussion there for a fuller discussion of why $r / L$ is a useful measure of resource abundance. $L$ measures the labor service flow whereas $r$ is a measure of the resource flow for any given $S$. 
on maximization of steady state utility is a very helpful simplification as it converts the problem to one that is comparable to a static problem.

In addition, there is something to be said on conceptual grounds for considering the case of what we think of as "pure" conservation. The consumer country is at one end of the conservationist spectrum; the conservationist country is at the other end. Considering these two special cases highlights the role of comparative harvesting institutions with particular clarity. Since choosing a low rate of discount is often associated with the conservationist component of the environmental community, our use of the term "conservationist" country has considerable appeal.

The conservationist government is assumed to maximize steady state utility. One mechanism for doing this is for the govemment to set a tax on harvesting and rebate the revenues to consumers. Consumers solve their own optimization problems in decentralized fashion, taking prices (inclusive of the harvesting tax) and incomes (including rebated government revenues) as given. The solution of the government's problem can be rearranged to obtain a supply curve linking steady state resource output corresponding to any existing relative price. That is, it gives us the supply curve of the perfectly regulated private sector. The relative supply curve is then constructed as the ratio of resource good supply to manufacturing supply as a function of the resource good's relative price.

The government's problem is to maximize steady state utility. As each consumer has the same utility function (given by (6)) and the same income, the government's problem can be written as one of maximizing an aggregate utility function, subject to the constraints that define the steady state.

$$
\max U(H, M)
$$

s.t. $H=r S(1-S / K)$ and $M=L_{M}=L-H a_{L H}=L-r(1-S / K) / \alpha$

The first constraint is given by (11) and the second follows from expressions (3), (12), and (5). The constraints indicate that both $\mathrm{H}$ and $\mathrm{M}$ are functions of $\mathrm{S}$ (in steady state). Substituting the constraints into (20) allows us to rewrite the problem as

$$
\max \mathrm{U}(\mathrm{H}(\mathrm{S}), \mathrm{M}(\mathrm{S}))
$$


and treat it as an unconstrained optimization. Taking the derivative of (21) with respect to $S$ yields $U_{H} d H / d S+U_{M} d M / d S=0$, where subscripts on $U$ denote partial derivatives. Dividing through by $U_{M}$, and noting that $\mathrm{U}_{\mathrm{H}} / \mathrm{U}_{\mathrm{M}}=\mathrm{p}$ leads to

$$
\mathrm{pdH} / \mathrm{dS}+\mathrm{dM} / \mathrm{dS}=0
$$

We now take the derivatives of the constraints to obtain $d H / d S=r(1-2 S / K)$ and $d M / d S=r /(K \alpha)$. Substituting these derivatives in expression (22) yields

$$
\operatorname{pr}(1-2 S / K)+r / K \alpha=0
$$

This first order condition can be rearranged to solve for the optimal steady state stock as follows.

$$
S^{*}=K / 2+1 /(2 p \alpha)
$$

Second order conditions for a maximum are easily verified.

It follows from (24) the desired resource stock $S^{*}$ is always greater than $K / 2$. This can be understood by simple intuition. If the stock is less than $\mathrm{K} / 2$, it is always possible to delay or lower current harvesting to build the stock to some level beyond $\mathrm{K} / 2$. Because the logistic growth curve is a single-peaked function of the stock (with a maximum at $S=K / 2$ ), for every steady state harvest arising from a stock less than $\mathrm{K} / 2$, the same steady state harvest is obtainable with a stock greater than $\mathrm{K} / 2$. Moreover, labor productivity is higher with a higher stock, so more labor is left to produce manufactures, leading to more manufactures. Therefore, if steady state welfare is to be maximized, the steady state stock must exceed $\mathrm{K} / 2$.

Unlike the open access consumer country, the conservationist country has a relative supply curve that is always upward sloping. An increase in p leads to a decrease in $\mathrm{S}$ and, since the optimal stock must exceed $\mathrm{K} / 2$, this decrease in $\mathrm{S}$ corresponds to an increase in the harvest, implying that the harvest or resource good output is always increasing in its relative price. Moreover we also know that less labor is available for manufactures when the resource stock falls, as both resource good output and the unit labor requirement in resource harvesting rise, implying that resource employment rises. Therefore, the harvest expands, manufactures contract, and the relative supply curve must always slope upwards. It follows from (14) that the relative supply curve (as a function of $S^{*}$ ) for the conservationist country is 


$$
H^{\mathrm{P}} / \mathrm{M}^{\mathrm{P}}=\left[r \mathrm{~S}^{*}\left(1-\mathrm{S}^{*} / \mathrm{K}\right)\right] /\left[\mathrm{L}-(\mathrm{r} / \alpha)\left(1-\mathrm{S}^{*} / \mathrm{K}\right)\right]
$$

We can then obtain the relative supply curve as a function of price, p, by substituting expression (24), which gives $S^{*}$ as a function of $p$, into (27).

$$
H^{P} / M^{P}=r(\alpha K p+1)(\alpha K p-1) /\left(2 p\left(2 \alpha^{2} K L p-r \alpha K p+r\right)\right)
$$

Strictly speaking, expression (28) only applies if $\mathrm{p} \geq 1 /(\alpha \mathrm{K})$. If this condition holds with equality, then (28) implies that relative (and absolute) resource good supply will be zero. For lower prices, the harvest remains at zero. The key points of this discussion are expressed in Proposition 2.

Proposition 2. For the conservationist country, the relative supply of the resource harvest to manufactures is always increasing in the relative price of the harvest good.

i) For $p<1 /(\alpha \mathrm{K})$, relative supply is zero.

ii)For $p>1 /(\alpha \mathrm{K})$, relative supply is given by $(28)$ :

iii) Relative supply cannot exceed $\mathrm{H} / \mathrm{M}=[\mathrm{rK} / 4] /[\mathrm{L}-(\mathrm{r} / 2 \alpha)]>0$.

iv) The conservationist relative supply curve is strictly upward sloping for all $p>1 /(\alpha \mathrm{K})$.

Proof: See Appendix.

A typical autarkic steady state for a conservationist country is depicted in Figure 2. Several comparative steady state effects are easy to establish. To start, expression (24) implies that for given $p$, the

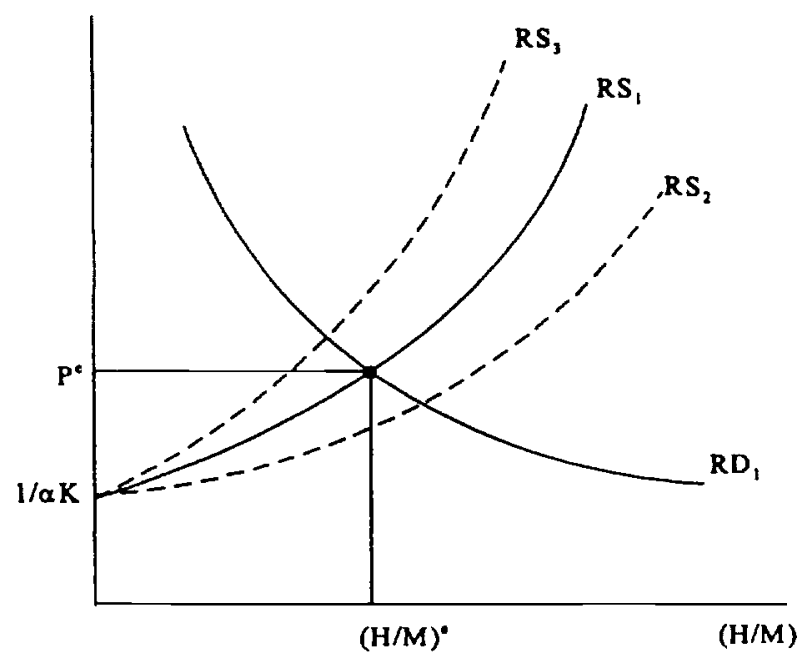

Figure 2: A utarky in the Conservationist Country 
optimal stock is independent of both $r$ and $\mathrm{L}$. Also, a little algebraic manipulation shows that, for a given $S^{*},(27)$ is a function of the ratio $r / L$, and an increase in $r$ or decrease in $L$ shifts the entire supply curve outwards. Therefore a faster rate of resource growth shifts the conservationist country's relative supply out as shown by $\mathrm{RS}_{2}$, while an increase in $\mathrm{L}$ shifts the relative supply inwards as shown by $\mathrm{RS}_{3}$. Proportional increases in $\mathrm{r}$ and $\mathrm{L}$ leave the supply curve unaffected. Therefore, our measure of factor abundance - the ratio of the intrinsic rate of resource growth to the scale of factor endowments - determines autarky relative prices. Using the relative demand curve given by $(10)$ and the conservationist relative supply curve given by $(28)$ it is algebraically tedious but conceptually straightforward to obtain solutions for autarky relative prices and the resource stock. These formulas are not required for our analysis so we do not report them here.

It is straightforward to determine the production tax needed to implement the conservationist harvesting policy. Specifically, the government sets a production tax $t^{*}$ such that $p=1 / \alpha S^{*}+t^{*}$. Producers (who take $p$ as given) enter, pay marginal labor costs of $1 /\left(\alpha S^{*}\right)$, pay $t^{*}$ per unit of harvest and hence earn zero profits. Substituting for $S^{*}$ using (24) and rearranging yields the following expression for the production tax: $t^{*}=p(\alpha K p-1) /(1+\alpha K p) \geq 0$. We know from Proposition 2 that $p$ cannot fall below $1 /(\alpha K)$, so $\alpha \mathrm{Kp}>1$ if the resource good is to be produced. This in turn tells us that $t^{*}$ is non-negative. If $p$ should fall below $1 /(\alpha \mathrm{K})$, then the income-maximizing solution is to specialize in $\mathrm{M}$ with $\mathrm{L}_{\mathrm{M}}=\mathrm{L}$ and $\mathrm{t}^{*}=0$. Tax revenues are rebated to consumers as lump-sum increments to income. The solution could be implemented in other ways as well. For example, the government could set a quota on the allowable harvest, auction these rights off to competitive bidders, and rebate proceeds to consumers. Alternatively, the government could create a monopoly manager of the resource and then allow this manager to maximize profits subject to a fixed price for the product, with any profits being distributed to domestic consumers.

Now suppose that we treat the conservationist country as a small open economy facing a fixed world (relative) price for the resource good. If this country trades at a fixed world price for the resource good in excess of the autarky price, $\mathrm{p}^{e}$, then reading off the corresponding quantities on $R S_{1}$ and $R D_{1}$ we find that since its relative supply of the resource good to manufactures exceeds its relative demand, it would export 
the resource good and import manufactures in free trade. Alternatively, if trade opened at a world relative price below this country's autarky price it would export manufactures and import the resource good. Moreover, for any given world price (in excess of $1 / \alpha \mathrm{K}$ ) if this country is sufficiently resource abundant as measured by the ratio of $r / L$, then it must export the resource good in free trade. In all of these cases the conservationist country would gain from trade.

\subsection{A Comparison of Relative Supply Curves}

In this section we compare the consumer and conservationist countries and show how differences in resource management regimes can be the basis of comparative advantage. In Figure 3 we illustrate typical relative supply curves for both countries. As shown, both relative supply curves start at $p=1 /(\alpha \mathrm{K})$, and intersect again at the relative price denoted $\mathrm{p}^{\mathrm{x}}$. Moreover, for prices $\mathrm{p}<\mathrm{p}^{\mathrm{x}}$ the relative supply curve of the consumer country lies outside that of the conservationist country, while for prices in excess of $\mathrm{p}^{\mathrm{x}}$, the conservationist relative supply lies outside of the consumer country relative supply.

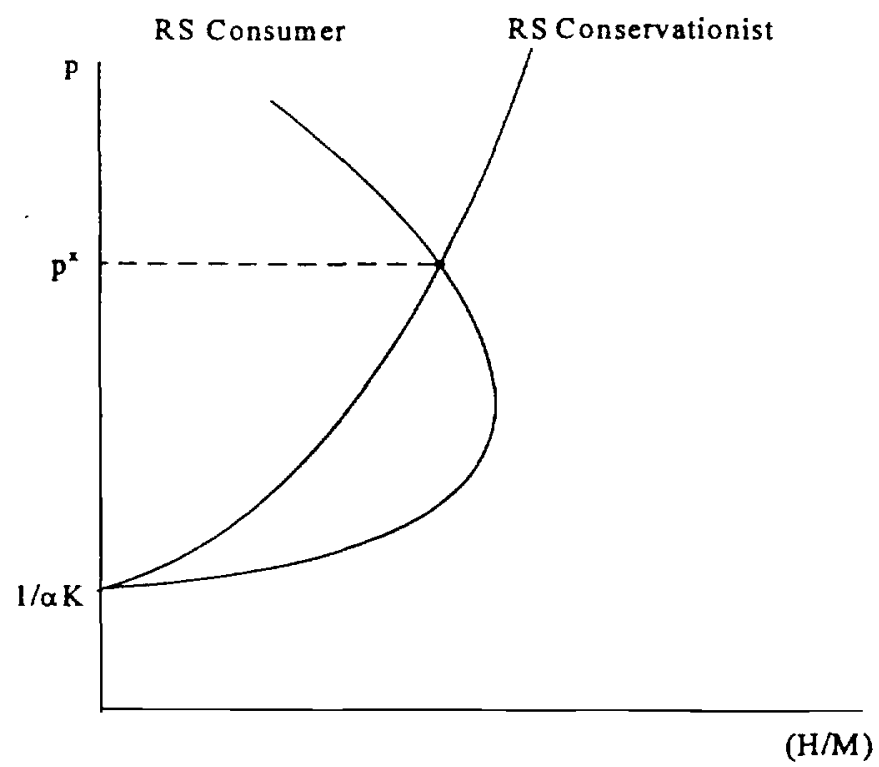

Figure 3: Consumer And Conservationist Supply Curves

These properties are not difficult to show. If $\mathrm{p}^{x}<1 /(\alpha \mathrm{K})$, then there are no resource rents to capture 
and neither country would produce the resource good, hence for prices $\mathrm{p}<1 /(\alpha \mathrm{K})$ both relative supply curves are at zero output. If the resource price were slightly above $1 /(\alpha \mathrm{K})$, then free entry in the consumer country would ensure complete rent dissipation and the stock would fall until the condition $p=1 /(\alpha S)$ held. In the conservationist country the government would ensure through tax (or quantity) instruments that rents were maximized at this higher price. This will necessarily require $p>1 /(\alpha S)$ in the conservationist country. Therefore, for any common resource good price, free entry in the consumer country drives its resource stock below that of our conservationist country. We can verify this result directly by using (16a) and (24). Moreover, it follows that the consumer country devotes more labor to harvesting than the conservationist country. (Recall that $\mathrm{L}_{\mathrm{H}}=\mathrm{H}^{\mathrm{P}} \mathrm{a}_{\mathrm{LH}}=(\mathrm{r} / \alpha)(1-\mathrm{S} / \mathrm{K})$ in both consumer and conservationist countries.)

Thus far our results accord well with conventional wisdom. The unregulated consumer country has a lower resource stock, and devotes more labor effort to harvesting the resource good. However, the consumer country may or may not produce more of the harvest good than the conservationist country. Because the consumer country has a lower stock than the conservationist country, growth equation (2) implies that when the consumer country's stock exceeds $\mathrm{K} / 2$, the steady state harvest in the consumer country must exceed that in the conservationist country. The consumer country also requires more labor in the resource sector than the conservationist country and would therefore have less labor left over to produce manufactures, implying a lower manufacturing output. As a result, the consumer country's relative supply lies outside that of the conservationist country when the resource good price is low, as shown.

When the resource good price is sufficiently high, the consumer country's relative supply curve bends backwards and approaches the vertical axis, as expressed in Proposition 1. Since the conservationist country's supply curve is always upward sloping, the two supply curves can and must intersect only once, as shown. These results are stated formally in Proposition 3.

Proposition 3. The consumer and conservationist relative supply curves intersect only once. The associated price, $\mathrm{p}^{\mathrm{x}}$, exceeds $1 /(\alpha \mathrm{K})$. Moreover:

i) For $p<p^{x}$, the relative supply of the consumer country exceeds that of the conservationist country; 
ii) For $p>p^{x}$, the relative supply of the conservationist country exceeds that of the consumer country;

iii) For any $p>1 /(\alpha \mathrm{K})$, the resource stock in the consumer country is smaller than in the conservationist country.

iv) For any $p>1 /(\alpha \mathrm{K})$, the amount of labor employed in the consumer country's resource sector exceeds that in the resource sector of the conservationist country.

Proof: See Appendix.

\section{International Trade between Consumer and Conservationist Countries}

Because relative demand is the same in each country, world relative demand is simply the same. As a result, it is possible to determine trade patterns by looking, for each country, at the difference between its relative supply and the common relative demand. For each country, the intersection of relative demand curve and the appropriate relative supply curve shows the autarky price of the resource good. If one superimposes the common relative demand curve on Figure 3, it is apparent that three different possibilities arise. First, as shown in Figure 4, it is possible that the relative demand curve intersects both relative supply curves at prices below $\mathrm{p}^{\mathrm{x}}$. In this case, the consumer country must have a lower autarky price of the resource good than the conservationist country. We refer to this case as the "mild overuse" case. The second possibility is that the relative demand curve intersects both relative supply curves at $\mathrm{p}^{\mathrm{x}}$. In this case, the countries have the same autarky prices and opening trade has no effect. We do not discuss this case further.

The third and final possibility is that the relative demand curve intersects both relative supply curves at prices above $\mathrm{p}^{\mathrm{x}}$, as shown in Figure 5 . In this case, the consumer country has the higher autarky price of the resource. For this to occur, the consumer country must be on the backward bending part of its supply curve and must be overusing the resource sufficiently severely that its relative steady state autarky output of the resource good is less than in the conservationist country. Accordingly, we refer to this as the "severe overuse" case. As the relative demand for the consumer country intersects its own relative supply curve only 
once, the free trade equilibrium must be unique.

\subsection{Mild Overuse}

Figure 4 illustrates the mild overuse case. We denote the autarky price of the resource good in the consumer country as $\mathrm{p}^{\mathrm{N}}$ and, as shown, this occurs at the intersection of the common relative demand and the consumer country relative supply. Similarly we can locate the autarky price in the conservationist country and denote it as $\mathrm{p}^{\mathrm{v}}$. In Figure 4 , the consumer country has a lower autarky relative price for the resource good since $p^{N}<p^{v}$. Therefore, the consumer country has a comparative advantage in the harvest good. If these two countries trade freely, the world equilibrium price must lie somewhere between the two

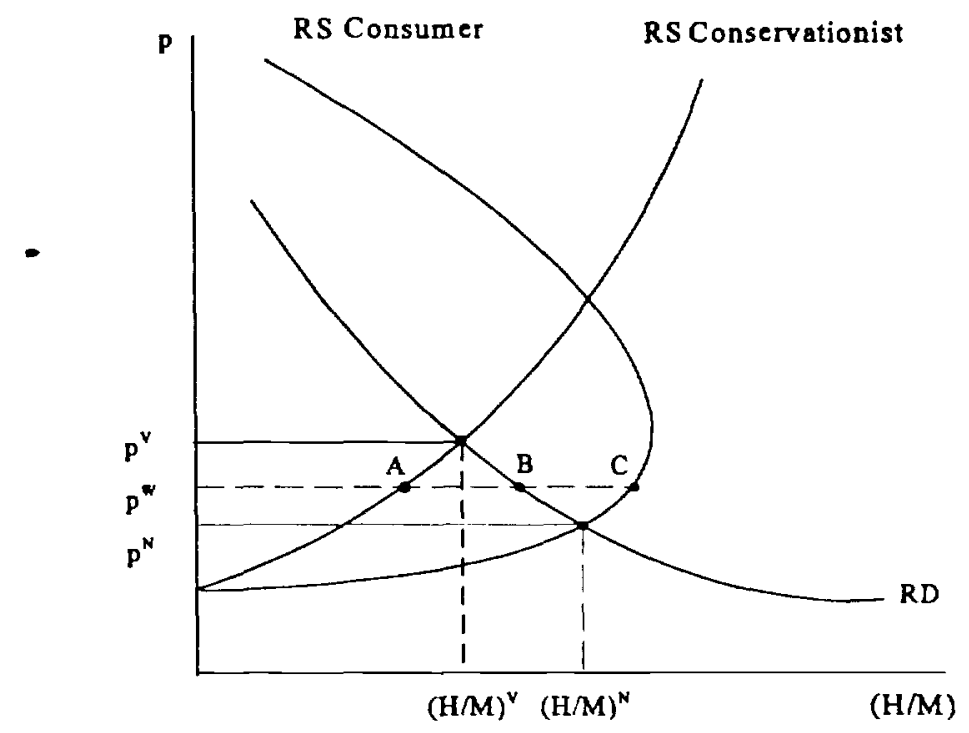

Figure 4: Mild Overuse

autarky prices at a level such as shown by $\mathrm{p}^{\mathrm{w}}$.

At this equilibrium price, the conservationist country consumes more of the renewable resource good than it produces, and must import this good. Similarly, the conservationist country produces more manufactures than it consumes and must therefore export manufactures. This gap between domestic demand

${ }^{9}$ Brander and Taylor (1995) examine the stability properties of a small open economy of the consumer country type and show global stability. A similar exercise is carried out for a two-country model with endogenous prices in Brander and Taylor (1996). 
and supply is shown (in relative form) by the distance BA. In contrast, the consumer country produces more of the harvest than it consumes and exports it in return for imports of manufactures. This gap between supply and demand in the consumer country is shown (in relative form) by the distance $\mathrm{CB}$. At the equilibrium price, $\mathrm{p}^{w}$, these relative magnitudes are such that the actual quantity of the resource good exported by the consumer country equals the amount imported by the conservationist country. ${ }^{10}$

From (16a) and (24) we know that the resource stock must fall with trade in the consumer country and it must rise in the conservationist country. The actual harvest of the resource good could also fall in the consumer country if the equilibrium world price were high enough to induce this country to operate on the backward bending portion of its supply curve. In this case, it is also true that both the harvest and manufacturing production would fall with the opening of (free) trade.

In this mild overuse case, the welfare implications for trade are very different for the two different countries. The conservationist country benefits from access to international markets. Since it has correctly internalized the externality arising from the common property resource, this economy is pareto efficient in autarky. As a result, the ability to trade at world prices different from autarky prices creates standard gains from trade. In contrast, the steady state welfare of the consumer country must fall because its steady state consumption of the two goods is reduced by trade. The consumer country increases its efforts in harvesting the resource good, and this over time reduces its resource stock. A lower resource stock in turn shifts its production possibility frontier inward, leading to losses despite the fact that it can trade at a world price $\mathrm{p}^{\mathrm{w}}$. that differs from its autarky price.

Proposition 4. In the mild overuse case, the consumer country has a lower relative price of the harvest good in autarky, exports the harvest good in free trade, reduces its resource stock in free trade, and has lower steady state utility in free trade. The conservationist country exports manufactures, raises its resource stock

${ }^{10}$ The trade pattern in the mild overuse case is similar to that derived within a static framework by Chichilnisky (1994). Chichilnisky shows that if we compare two otherwise identical countries that differ only in their property rights regimes, then the open access country will export the resource intensive product in free trade. 
in free trade, and gains from trade.

Proof: See Appendix.

\subsection{Severe Overuse}

The case of severe overuse is illustrated in Figure 5. In this case the autarky price in the conservationist country, $\mathrm{p}^{\mathrm{v}}$, is lower than that in the consumer country. If we allow these two nations to trade, the world relative price $p^{w}$ must lie somewhere between the two autarky prices. At $p^{w}$, the supply of the harvest good in the conservationist country exceeds its demand and it will export the resource good in the trading steady state. The gap between demand and supply (in relative terms) is given by the distance CB. For the consumer country, the demand for the resource good exceeds its supply so this country imports the

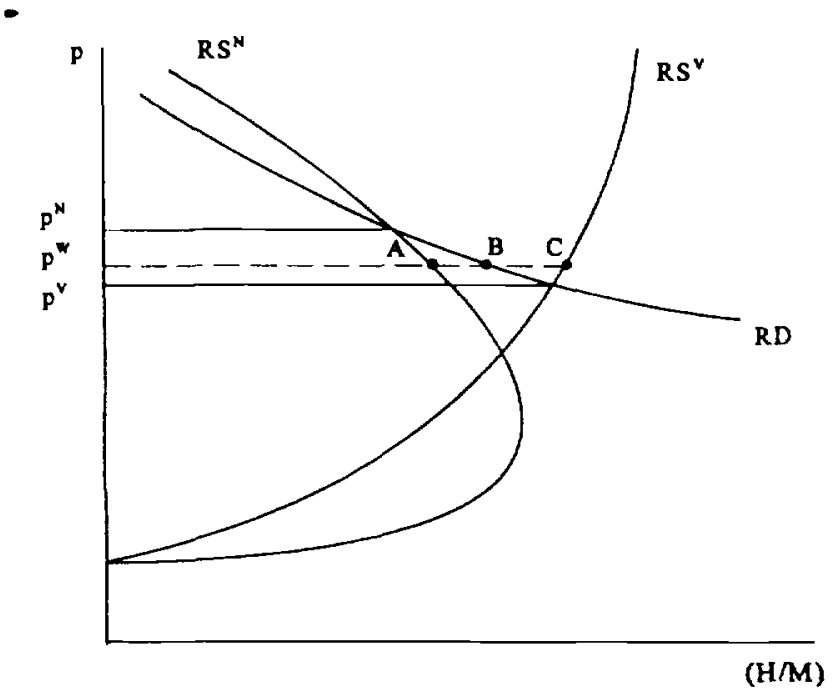

Figure 5: Severe Overuse

resource good and exports manufactures. The gap between demand and supply (in relative terms) is given by the distance $A B$. As $p^{w}$ is the market clearing relative price, the relative excess supplies and demands must equate the actual import and export volumes for each good.

A striking feature of this case is that the conservationist country exports the resource good while the consumer country imports the resource good. This shows that weak regulation of the renewable resource 
does not confer on the low standard consumer country a comparative advantage in the resource good. Instead we find that a well-managed resource can be relatively competitive in the long run. It is the conservationist country that exports the resource good in the trading steady state.

It is also worth emphasizing that the world relative price is below the consumer country's autarky price. This implies that trade leads to a rebuilding of the consumer country's resource stock. Also, since the consumer country is operating on the backward bending portion of its relative supply curve, its output of both manufactures and the resource good must rise. Conventional measures of total factor productivity in the consumer country would rise because of trade.

The welfare effects of trade in the severe overuse case are of considerable interest. The conservationist country gains from trade for the standard reasons. In this case, however, the consumer country also gains because the effect of trade is to mitigate the open access market failure. As a consequence, the consumer country's steady state utility is raised by free trade. In this case, free trade turns out to be the environmentalist's best friend.

Proposition 5. In the severe overuse case, the conservationist country has a lower relative price of the harvest good, exports the harvest in the free trade, and gains from trade. The consumer country exports manufactures, imports the resource good, and has higher steady state utility in free trade.

Proof: See Appendix.

\subsection{Determinants of Severe or Mild Overuse}

We have not yet specified the factors that determine whether there is mild or severe resource overuse. The underlying factors include the structure of preferences, primary factor indowments, and resource growth. The role of preferences can be readily determined using Figure 4. Starting from mild overuse as illustrated in Figure 4, suppose preferences shift in the direction of the resource good. This would shift the relative demand curve outward and, ultimately, would induce severe overuse. As for labor (or population) endowments, the results of section 3 imply that an increase in $L$ causes the turning point for the open access relative supply curve to occur at a lower relative price. Therefore, population increases would 
eventually cause severe overuse. Finally, if the resource growth rate $r$ falls, then again the consumer country's relative supply curve for the resource turns back sooner. A sufficient reduction in $r$ necessarily ensures a severe overuse equilibrium. We note, however, that we cannot carry out the conceptual experiment of lowering $r$ too far, as we require $r>\alpha \beta L$ to insure the existence of equilibrium.

Putting these results together shows that whenever the resource is under severe pressure in autarky, because the resource base grows slowly, because the population is large, or because the taste for the resource good is strong, then the severe overuse case arises. This is the case in which the costs of the open access market failure are greatest, but it is precisely this case where international trade is most useful. Trade mitigates the market failure, allowing the consumer country to benefit from the conservationist policy' of the other country, and allowing both countries to experience steady state gains from trade.

\section{Discounting}

One important simplification in our analysis is that we do not deal explicitly with discounting. The consumer country suffers from an open access problem and acts to dissipate rents from the resource at each point in time. This would be optimal if the discount rate were infinite. Conversely, the conservationist country seeks to maximize steady state utility, in effect granting no preference to present over future utility. The analytical simplicity of the paper arises in large part from the fact that the model for each country reduces to the equivalent of a static labor allocation problem so no explicit intertemporal maximization is required. We regard this as a useful benchmark but we admit that it does not fully address certain potentially interesting dynamic considerations.

The consumer country model is readily defensible in that the question of what the social discount rate might be is moot provided that the resource is assumed to be unregulated and subject to open access. For the conservationist country, however, some readers might prefer a model that allowed the conservationist country to maximize the discounted value of utility using a finite but positive discount rate. We certainly acknowledge that the justification for maximizing steady state utility is not completely established. The standard argument for considering steady state utility contains two steps. The first step is to assert that 
intertemporal equity considerations should rule out discounting of future utility. (This is the original point made by Ramsey (1928) who states that "we do not discount later enjoyments in comparison with earlier ones, a practice which is ethically indefensible and arises merely from the weakness of imagination...”). The second step is to suggest that rejecting discounting leads to maximization of steady state utility.

Neither of these steps is uncontroversial. The question of whether discounting of utility is ethically defensible remains a point of debate among economists and philosophers, and we are not going solve (or even address) that issue here. Secondly, it is not true that assuming a zero discount necessarily implies maximization of steady state utility. If the discount rate is zero, then the present value of utility is not finite (i.e. it does not "converge") and there may be no solution to the associated maximization problem. What is true, however, is that maximization of steady state utility implies that there is no preference for present over future utility. In this sense maximization of steady state utility is "consistent with" the absence of discounting. Secondly, in most renewable resource models, if one maximizes the discounted value of utility and lets the discount rate approach zero, then the solution approaches maximization of steady state utility. (See Clark (1990, Ch. 2, pp. 42-43).) We believe this to be true of our model but have not formally established it. However, we would also argue that consideration of steady state utility is interesting in its own right, and provides a useful analytical simplification, even if its welfare theoretic foundation is open to some disagreement.

It is possible, but difficult, to incorporate explicit discounting in the conservationist country's problem. As pointed out by a referee, the resulting problem is similar to standard optimal accumulation problems, although the two-sector, two country aspect of the model makes it more complicated than standard models. One can build up intuition from simpler cases. In particular, if prices could be taken as given (as for a small open economy), then the optimal harvesting rule for the conservationist country must satisfy $\left[G^{\prime}(S)\right.$ $\left.w_{\mathrm{LH}^{\prime}}{ }^{\prime}(\mathrm{S}) \mathrm{G}(\mathrm{S}) /\left(\mathrm{p}-\mathrm{wa}_{\mathrm{LH}}\right)\right]=\delta$, where $\delta$ is the discount rate. (This can be inferred from Clark (1990, p. 40).) However, consideration of terms of trade effects arising from endogenous prices in our model make the analysis more complicated. 
The reader should be alerted to the fact that there can be a sharp difference between models with and without discounting. For example, Smith (1968) shows, using a non-discounting model of renewable resource use, that it is efficient to regulate the stock so that the steady state stock is to the right of the maximum of the growth function (i.e. at a stock greater that $\mathrm{K} / 2$ using our notation). In a comparable model with discounting, however, Brown (1974) shows that the optimal stock occurs to left of the maximum of the growth function. In the autarky version of our model, the conservationist country does choose a steady state stock greater than $\mathrm{K} / 2$, but discounting would tend to reduce the optimal stock.

We note in passing that the supply curve for an optimally managed country with a positive discount rate may be backward-bending, in contrast to our conservationist country's upward sloping supply curve. In models similar to (but simpler than) ours it can be shown (as in Clark (1990, Ch.5, pp.131-142)) that two identical countries that differ only according to discount rates (including the case in which one has an infinite discount rate) have supply curves that cross only once. Our analysis depends only on this single-crossing requirement, so the basic principles of our analysis should generalize.

\section{Concluding Remarks:}

Conventional wisdom suggests that if a country adopts weak resource management practices, then firms in its resource industry will have a "competitive" advantage over their rivals in more tightly regulated countries. Free international trade should lead to an expansion of both production and exports of resource intensive products from any such low standard country and result in a parallel contraction in high standard countries. This direct link from weak resource management to "competitiveness" and then to trade flows is at the heart of much of the debate over the environmental implications of free international trade. On the other hand, it seems clear that a badly managed resource may ultimately be a subject to over exploitation and impaired productivity, leading to a loss in competitiveness.

This paper examines the effect of differential resource management standards on trade flows and comparative advantage. We consider trade between two economies, each with a national (as opposed to trans-boundary) renewable resource stock. One country, the "consumer" country, manages the resource as 
on open access resource (i.e. without property rights), so all domestic producers have free and open access to the resource. The other country, the "conservationist" country, limits access to the resource so as to maximize the steady state welfare of its domestic residents. We distinguish two cases. One case is referred to as "mild overuse" and gives rises to a situation in which the consumer country is a net exporter of the resource good in steady state. Essentially, this country's weak resource controls provide an effective comparative advantage to the resource sector. In this case, the consumer country loses from trade, while the conservationist country gains from trade. This case might be said to support the conventional wisdom.

It is also possible that the consumer country might be in a situation of "severe overuse" in autarky. In this case the consumer country becomes a steady state importer of the resource good after trade opens and, strikingly, both countries gain from trade. This is the opposite of what we have characterized as conventional wisdom. In those cases where the resource is most endangered in autarky (the severe overuse case) allowing trade lowers resource use in the consumer country, induces it to partially rebuild its over- exploited resource stock, makes the consumer country a net resource importer, and provides gains from trade to both countries. Thus a major market failure in the consumer country is mitigated by opening trade, whereas a more mild market failure is worsened by trade. 


\section{Appendix: Proofs of Propositions.}

\section{Proof of Proposition 1:}

The main point of Proposition 1 is that the supply curve for the resource good (i.e. for the harvest) in the consumer country is a backward-bending function of the price. The relative supply curve, RS(p) is given by expression (17) of the text, which is reproduced as (A1).

$$
R S(p)=H^{p} / M^{p}=(r /(\alpha p))(1-1 /(\alpha p K)) /(L-(r / \alpha)(1-1 /(\alpha p K)))
$$

The method of proof is to show that the supply function $\mathrm{RS}(\mathrm{p})$ has a maximum at a finite value of $\mathrm{p}$, denoted $p^{c}$. It then follows that the supply is increasing for prices less that $p^{c}$ and decreasing for prices above $p^{c}$. The derivative of (Al) and its roots are somewhat tedious to calculate, but a useful expression for $\operatorname{RS}^{\prime}(\mathrm{p})$ is

$$
R S^{\prime}(p)=r\left[-\alpha^{3} p^{2} K^{2} L+\alpha^{2} p^{2} K^{2} t-2 r \alpha p K+2 L \alpha^{2} p K+r\right] / p^{2}\left[r \alpha p K-L \alpha^{2} p K-r\right]^{2}
$$

The denominator of (A2) is obviously positive as it is the square of a real number. The numerator of (A2) is a quadratic function in $p$ with roots

$$
\left[(\alpha \mathrm{L}-\mathrm{r}) \pm(\alpha \mathrm{L}(\alpha \mathrm{L}-\mathrm{r}))^{1 / 2}\right] /[\alpha \mathrm{K}(\alpha \mathrm{L}-\mathrm{r})]
$$

Expression (A3) can be rewritten as

$$
\left[1 \pm(\alpha \mathrm{L} /(\alpha \mathrm{L}-\mathrm{r}))^{1 / 2}\right] /(\alpha \mathrm{K})
$$

The term ( $\alpha \mathrm{L}-\mathrm{r}$ ) is positive by condition (15). It then follows from (A4) that one root in (A4) is positive and one is negative. The positive root in (A4) is the value $p^{C}$ referred to in Proposition 1. When $p$ takes on this value, $R^{\prime}(p)$ is equal to zero, and it is straightforward to show (by taking the second derivative of $R S$ ) that RS reaches a maximum (rather than a minimum) at this point. Thus the critical value of $p$ is

$$
p^{c}=1 /(\alpha K)+(\alpha L /(\alpha L-r))^{1 / 2} /(\alpha K)
$$

i) The fact that relative supply is 0 if $p \leq 1 / \alpha \mathrm{K}$ follows from equation (16). For the resource good to be produced its price must equal its cost of production, which implies $p=1 / \alpha \mathrm{S}$. As $\mathrm{S}$ cannot exceed $\mathrm{K}$, a price less $1 / \alpha \mathrm{K}$ or less implies that production of the resource good cannot recover its costs no matter how much the stock grows (up to its maximum) and therefore will not be produced by competitive producers. At $p=1 /(\alpha K)$, relative supply is 0 from (Al). 
ii) The simplest way to prove that relative supply is increasing up to $\mathrm{p}^{c}$ is to use (A2) to establish that $\operatorname{RS}^{\prime}(\mathrm{p})$ is positive at $p=1 /(\alpha \mathrm{K})$. It is also transparent from (A2) that $\mathrm{RS}^{\prime}(\mathrm{p})$ approaches 0 as $\mathrm{p}$ gets sufficiently large as there are terms in $\mathrm{p}^{3}$ in the denominator but only terms in $\mathrm{p}^{2}$ in the numerator of (A8). Combined with the fact that $R S(p=1 / \alpha K)=0$ and the existence of the positive critical point given by (A9), the result follows. iii) This is just a matter of logical consistency. There is a unique maximum value of $H^{p} / M^{p}$. The value of $p$ (denoted $\mathrm{p}^{\mathrm{C}}$ ) and the value of $\mathrm{S}\left(\right.$ denoted $\mathrm{S}^{\mathrm{C}}$ ) associated with this value must be consistent with each other in the sense that $p=1 /(\alpha S)$ as given by $(16 a)$.

iv) To solve for $S^{C}$ we can use expression (A5) and the relationship that $p^{C}=1 /\left(\alpha S^{\complement}\right)$ (just established in part iii of this proof). Rewriting this as $S^{c}=1 / \alpha \mathrm{p}^{c}$, substituting in (A5) and doing some manipulation yields

$$
S^{C}=[K(\alpha L-r) / r]\left[(\alpha L /(\alpha L-r))^{1 / 2}-1\right] .
$$

Simply taking the derivative of $S^{c}$ with respect to $L$ and $r$ establishes that $d S^{c} / d L>0$ and $d S^{c} / d r<0$, as was to be shown.

\section{Proof of Proposition 2:}

The key point of Proposition 2 is that the relative supply curve for the conservationist country is always upward sloping. This can be shown after establishing statements i) and ii) of the Proposition.

i) If $p<1 /(\alpha K)$ then the marginal value of the resource good as given by the price is less than the marginal opportunity cost of production, even if labor is at its maximum productivity (which occurs when $K=S$ ). Therefore it cannot be efficient to produce any supply if $p<1 / \alpha \mathrm{K}$.

ii) If $p>1 / \alpha \mathrm{K}$, then relative supply is determined as shown in the text, leading to expression (28).

iii) The maximum value of $\mathrm{H} / \mathrm{M}$ is obtained by allowing $\mathrm{p}$ to approach infinity in expression (28) of the text. In this case $H / M$ approaches the value $(r K / 4) /[L-r / 2 \alpha]$. This value must be positive in light of condition (15). iv) The method of proof is simply to take the derivative of (28) with respect to $p$ and demonstrate that this derivative is positive. This is a computationally tedious calculation that we have done using MAPLE V. We do not take the space to report the steps here, but can provide them on request. 


\section{Proof of Proposition 3:}

Proposition 3 specifies the comparative location of relative supply curves (as functions of price) for the consumer and conservationist countries. The method of proof is by direct construction using Figure 3 . In Figure 3 price is shown on the vertical axis and relative supply on the horizontal axis. It is established in the text that relative supply curves for both countries "start at" (i.e. have a vertical intercept at) $p=1 / \alpha K$. It can then be shown by direct comparison of (17) and (28) that for values of $\mathrm{p}$ slightly greater than $1 / \alpha \mathrm{K}$ the consumer country (given by (17)) has greater relative supply, but that for sufficiently high prices the conservationist country (given by (28)) has higher relative supply. Given the shapes of the curves as established in Propositions 1 and 2, Proposition 3 follows directly.

\section{Proof of Proposition 4:}

Proposition 4 states that the consumer country exports the resource good and loses from trade in the mild overuse case. The line of proof is as follows. The mild overuse case is defined by the diagrammatic situation in Figure 4. The characteristics of the relative supply curves have been established in Propositions 1-3, and the observation that "mild overuse" case exists follows from simply drawing a relative demand curve in the appropriate place. As the location of the relative demand curve depends on parameters that are independent of relative supply (notably $\beta$ ), it is clear that a situation such as that illustrated in Figure 4 is feasible.

The associated algebra can be readily written down but is tedious and is not reported here because the diagrammatic reasoning provides a complete proof. In any case, it is a defining characteristic of the mild overuse case that the world price of the resource good lies above the autarky price of the consumer country and below the autarky price of the conservationist country. It follows from the shape of the relative supply curves, as shown in Figure 4, that the consumer country will necessarily export the resource good and the conservationist country will necessarily import it. The final point to prove is that consumer country will actually lose from trade in this case. This case is similar to the case of the small open economy described in Brander and Taylor (1995) where the proof is outlined in more detail. However the following line of reasoning is sufficient. Before trade, income in the consumer country is $\mathrm{L}$, since the wage is $\mathrm{l}$ and total 
income is wL. The price of the numeraire good is 1 and the price of the resource good is $p^{N}$. In the trading steady state, this country still produces some manufactures, its wage is therefore 1 , and nominal income is therefore still $\mathrm{L}$. The price of the numeraire good is unchanged at 1 , but the price of the resource good has risen. As a representative consumer now faces higher prices with the same nominal income, it follows immediately that welfare falls in the consumer country. The conservationist country must, on the other hand, gain from trade as it has no domestic distortions and simply obtains the standard exchange and production gains from trade for a competitive economy.

\section{Proof of Proposition 5:}

Proposition 5 establishes the trade pattern and welfare effects of trade for the "severe overuse" case. As with the mild overuse case, the existence and basic properties of this case follow from the properties of the relative supply curves as established in Propositions 1-3 and from the fact that the demand curve shown in Figure 5 is a feasible demand curve. (It can be easily shown that a sufficiently large value of $\beta$ will shift out the relative demand curve for the resource good sufficiently to allow the severe overuse case to arise.) In this case, the world steady state price of the resource good ends up above the autarky price in the conservationist country and below the autarky price in the consumer country. It follow's from Figure 5 that the conservationist country is a net exporter of the resource good in this case, and the consumer country is a net importer. The fact that the consumer country gains from trade is the mirtor image of Proposition 4 . In this case we observe that, compared to autarky, the trading steady state offers the consumer country the same nominal income, the same price of the numeraire good, and a lower price for the resource good. Its steady state welfare must rise. The conservationist country must also gain because it is an undistorted competitive economy that necessarily receives consumption and specialization gains from trade. Note that the conservationist country does not have the same nom inal income after trade as in autarky. Its nominal income rises because the tax cum tariff on the resource good generates more revenue under free trade than in autarky. Thus, even though consumers in the conservation ist country experience increased prices for the resource good, their income gains more than offset this effect. 


\section{REFERENCES}

Barbier, E.B., M. Rauscher, 1994, Trade, tropical deforestation and policy interventions, Environmental and Resource Economics 4, 75-90.

Bhagwati, J., 1971, The generalized theory of distortions and welfare, In: J. Bhagwati, R. Jones, R. Mundell and J. Vanek ed. Trade, balance of payments and growth: Essays in honor of Charles Kindleberger (NorthHolland, Amsterdam).

Brander, J.A. and M.S. Taylor, 1995, International trade and open access renewable resources: The small open economy case, NBER Discussion Paper 5021 (Cambridge, MA).

Brander, J.A. and M.S. Taylor, 1996, Open-access renewable resources: Trade and trade policy in a twocountry model, NBER Discussion Paper 5474 (Cambridge, MA).

Brown, G., 1974, An optimal program for managing common property resources with congestion externalities, Journal of Political Economy, no. 82, 163-173.

Brown, L.R., 1995, Nature's limits, In: Brown et. al. ed. State of the world (Norton, New York).

Chichilnisky, G., 1994, North-south trade and the global environment, American Economic Review 84, 851874.

Chichilnisky, G., Global environment and North-South trade, Asian Joumal of Economics and Social Studies $10,185-201$.

Clark, C.W., 1990, Mathematical bioeconomics: The optimal management of renewable resources (Second edition) (Wiley, New York).

Clarke, H.R., W.J. Reed and R.M. Shrestha, 1993, Optimal enforcement of property rights on developing country forests subject to illegal logging, Resource and Energy Economics 15, 271-93.

Clemhout, S. and H. Wan, 1991, Environmental problems as a common-property resource game, In: R.P. Hamalainen and H.K. Ehtamo ed. Lecture notes in control and information sciences (Springer-Verlag, Berlin).

Copes, P., 1970, The backward bending supply curve of the fishing industry, Scottish Journal of Political Economy, no. 17, 69-77.

Deardorff, A.V., 1973, The gains from trade in and out of steady-state growth, Oxford Economic Papers 25, 173-191.

Estey, D.C., (International Trade and the Environment), 1995. Background paper for the use of the National Council of World Wildlife Federation's Corporate Conservation Council at the SYNERGY 95 Meeting in Geneva, May 1-2.

Gordon, H.S., 1954, The economic theory of a common property resource: The fishery, Journal of Political Economy, no. 62, April, 124-42. 
GATT Secretariat, 1992, Trade and the environment, Chapter 2 in International Trade 1990-1991. Geneva: General Agreement on Tariffs and Trade.

Jaffe, A., S. Peterson, P. Portney and R. Stavins, 1995, Environmental regulation and the competitiveriess of U.S. manufacturing: What does the evidence tell us, Journal of Economic Literature 33, 132-163.

Kemp, M.C. and N.V. Long, 1984, The role of natural resources in trade models In: R.W. Jones and Peter B. Kenen ed. Handbook of International Economics, no. 1, (North-Holland, Amsterdam).

Lipsey, R. and K. Lancaster, 1957, The general theory of the second-best, Review of Economic Studies 24, $11-32$.

Mason, C.F. and S. Polasky, 1994, Entry deterence in the Commons, International Economic Review 5, no. $35,507-526$.

McCaskill, K.A., 1994, Dangerous liaisons: The World Trade Organization and the Environmental Agenda, Policy Staff Paper no. 94/14, (Department of Foreign Affairs and International Trade, Ottawa, Canada).

McRae, J.J., 1978, Optimal and competitive use of replenishable natural resources by open economies, Journal of International Economics, no, 8, 29-54.

Munro, G.R. and A.D. Scott, 1985, The economics of fisheries management, In: A.V. Kneese and J.L. Sweeney ed. Handbook of natural resource and energy economics 2, no. 14, North-Holland, Amsterdam).

Neher, P., 1990, Natural resource economics: Conservation and exploitation (Cambridge University Press, Cambridge).

OECD, 1995, Report on trade and environment to the OECD council at the ministerial level, (OECD, Paris).

Pearce, D.W. and J. Warford, 1993, World without end: Economics, environment and sustainable development (Oxford University Press, Oxford).

Plourde, G.C., 1971, Exploitation of common-property replenishible resources, Western Economic Journal 9, 256-266.

Rauscher, M., 1993, On ecological dumping, Oxford Economic Papers, 46, 822-840.

Scott, A. and C. Southey, 1969, The problem of achieving efficient regulation of a fishery, In: A. Scott ed. Economics of fishery management: A symposium, Institute of Animal Resource Ecology, (University of British Columbia, Vancouver, B.C.)

Schaefer, M.B., 1957, Some considerations of population dynamics and economics in relation to the management of marine fisheries, Journal of the Fisheries Research Board of Canada, no. 14, 669-681.

Smith, V., 1968, Economics of production from natural resources, American Economic Review 58, 409-31.

UNCTAD, 1994, Trade and Environment and UNCED Follow-up Activities in UNCTAD, note prepared by the UNCTAD Secretariat for the Second meeting of the Commission on Sustainable Development, Geneva. 